\title{
Potential Retrofit of Existing Sultan Ismail Parliament Building, Johor to Green Building
}

\author{
Mohd Norazam Yasin ${ }^{1, *}$ Abd Halid Abdullah ${ }^{1}$, Hazrul Abdul Hamid ${ }^{1}$, and Nur Shahirah \\ Nadhilah Wahab ${ }^{2}$ \\ ${ }^{1}$ Faculty of Civil and Environmental Engineering (FKAAS), Universiti Tun Hussein Onn \\ Malaysia, Batu Pahat, 86400 Johor, Malaysia \\ ${ }^{2}$ Faculty of Civil Engineering (FKA), Universiti Teknologi Malaysia, Johor Bahrut, 81310 \\ Johor, Malaysia
}

\begin{abstract}
The concept of retrofitting an existing building towards green building was introduced to move towards greener development. This paper investigates the benefits of retrofitting an existing building to green building. The potential retrofit of the existing Sultan Ismail Parliament building was also determined and later the elements of the building to be retrofitted were proposed. The Sultan Ismail Parliament building is one of the newest development that serves as the Johor state administrative center under Iskandar Malaysia. Therefore, this paper focuses on whether the existing building has fulfilled all of the green building elements. A set of questionnaire was distributed to the targeted respondents who were the engineers, architects, technicians, staffs and those who were involved in the development of the Sultan Ismail Parliament building. A total of 60 respondents was involved. Based on the analyzed data, it shows that the existing building has fulfilled only one of the green building elements which is the Indoor Environmental Quality. The items that scored 3.5 and above mean index under this element include the daylight glare is not bothering, the ventilation in the building is adequate, inspections are done regularly, smoking regulation is implemented and the number of openings of windows and doors is sufficient. While it shows that other elements were only partially fulfilled. The criteria that achieved below 3.5 mean index values is considered to be the potential elements that could be used for future retrofitting initiative.
\end{abstract}

\section{Introduction}

The construction industry is one of the biggest industries in the world today. Global warming, climate change, soil erosion, air pollution and water pollution are some of the main problems arise due to the construction industry. Not only that it affects the environment, it also will affect the human health, comfort and productivity. Later, the concept of sustainable construction was introduced into the construction industry to promote the healthier construction environment to the people and to the nature itself.

\footnotetext{
* Corresponding author: norazam@uthm.edu.my
} 
Malaysia is also one of the countries that are moving towards greener development. The Green Building concept was introduced. It serves as the solution which involves examining the interaction between the building elements in order to optimize the energy and the environmental performance (1). Hence, green building was introduced and established to promote the awareness of constructing sustainable to reduce the impact of construction. However, some of the building has not yet fulfilled the green building elements since some of them are still unaware of the importance of green building in a construction. The new Sultan Ismail Parliament building which is located at Kota Iskandar, Johor is taken into the main consideration in this study. The building claims to promote sustainability, reducing energy cost and increasing long term usage. Therefore, this paper is intended to study the benefit of retrofitting an existing building to green building, to determine whether the existing Sultan Ismail Parliament building has yet fulfilled all of the green building elements and to propose significant elements that could be retrofitted.

\section{Green building and retrofitting}

According to a report done by the Willmott Dixon Group, the construction industries uses $45 \%$ to $50 \%$ of global energy, nearly $50 \%$ of worldwide water usage and around $60 \%$ of total raw material use. It was also said that this industry contributes to $23 \%$ of air pollution, $50 \%$ of climate change gases, $40 \%$ of pollution of drinking water and $50 \%$ of landfill wastes. The development of new technologies means that building retrofits can allow for significant reductions in energy and water usage (2). In order to reduce the impact to the environment, the concept of sustainable construction was introduced and implemented since a few decades ago. Green Buildings should be designed and operated to reduce the overall environmental impact of the building and surrounding area (3). The concept of green development was introduced later and the terms such as the 'green building', 'green home' and 'green construction' are all connected to increase the building performance, to enhance the energy, water and resource efficiency, to protect the occupants health and comfort, to reduce waste and reduce negative impact to the environment. According to Green Building Index, a green building focusses to increase the efficiency of resource use, to reduce the building impact on human health and the environment during the building's lifecycle (4). There are six main green building elements which are being focused on including the energy efficiency, indoor environmental quality, sustainable site planning and management, materials and resources, water efficiency and innovation. All of these elements are important as they serve as the guideline to be used to achieve the green building strategy (5).

This green building concept, however, was only introduced a few years ago. Some of the buildings were built long before that such as the heritage buildings and there are also some of the new buildings have not followed the green building strategy and thus did not fulfilled the concept. Therefore, the retrofitting concept was later introduced. Retrofitting is one way to remodel or to modify an existing building towards green building. Retrofitting is not only improves the performance of the existing buildings, but it also reduces the carbon footprint to the environment. According to Garnaut (6), sustainable retrofit helps to lower the greenhouse emissions, lowers the energy usage and provides healthier workplace (7). Retrofitting can be done on any types of building and it is depending on the owner to determine what is the main objective and the scope of the retrofitting. To successfully achieve the retrofit, several strategies were introduced to ease the process. This includes the retrofit timing and duration, integrated planning, design and documentation, setting a retrofit budget, incorporating sustainability and replacing existing building system (8). 


\section{Sultan Ismail Parliament Building}

The Sultan Ismail Parliament building is located at Kota Iskandar, Johor Bahru. The Iskandar Malaysia, Figure 1 was established under the Ninth Malaysian Plan as one of the regional development corridors. The Kota Iskandar was developed by the Cahaya Jauhar Sdn. Bhd and the key plan were to fulfill the sustainable concept. It was the first fully integrated solid waste collection and disposal system, the first non-intrusive security plan with direct link to the police and the first district cooling system outside of Kuala Lumpur (9). The building was constructed completely in the year 2008 and is now serving as the Johor state Assembly Hall. The land area is approximately 6.67 hectares and it was inspired by the Moorish-Andalusian and Johor-Malay design. The main building consists of five blocks and four stories each. There are also libraries, archives, operation rooms, banquet halls, and three themed courtyards.

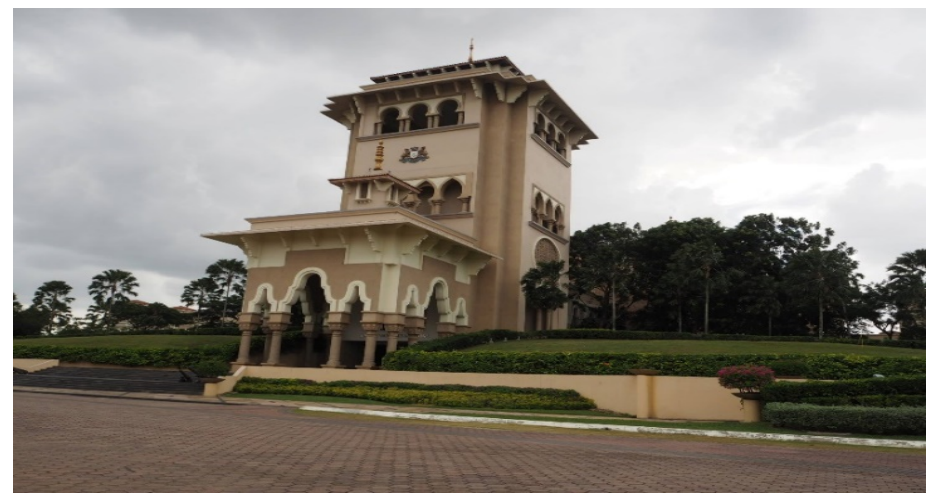

Fig.1 Sultan Ismail Parliament Building.

\section{Methodology}

The methods used to achieve the objectives of the study consist of three phases. The first phase was identifying the research title, the background study, the problem statement, and the objectives of the study and the scope of study. The second phase was to study the benefits of retrofitting the existing building to green building by intensive research through past studies. The questionnaire survey was done to determine the potential of Sultan Ismail Parliament building. The questionnaire was designed into three parts, A, B and C. Section A was the demographic information of the respondents where the questions such as the gender, age, profession and work experience were asked. Respondents were required to answer by ticking the suitable answer provided. As for section B, the questions involves the respondent's opinion on the green building elements that have been implemented in the parliament building. Section $\mathrm{C}$ was asking about the respondent's agreement to suggest the best additional elements that can be implemented to support initiative in the future for the Sultan Ismail Parliament building. The respondents were required to answer by following the Likert Scale of agreement which have five main measures; strongly disagree, disagree, neither agree nor disagree, agree and strongly agree. A set of questionnaire was distributed to the developer of the Sultan Ismail Parliament building and to the staffs who are currently working at the building itself. A total of 60 respondents was involved in this study. The third phase was the analysis of data and the discussion were made. The data collected from the survey were analysed by using the mean index method. The data will also be analysed by using Spearman's correlation analysis to test the relationship of two variables. 


\section{Results and discussion}

\subsection{The potential of Sultan Ismail Parliament Building towards green building initiative}

The Figure 2 shows the mean index for the Energy Efficiency element. Based on the figure, it shows that the most efficient sub-elements that has been implemented with a mean index of 4.02 is the number of lightbulbs installed is adequate and not excessive. This is because the lightbulbs were installed mostly in the working area where it needs sufficient lighting. Furthermore, this building enhances the natural lighting by designing skylights and openings that allows natural lighting into the building. Hence, this ensures that the artificial lightings were installed according to the requirement. While the lowest mean index is 1.82 which is the building is implementing a solar energy system. It shows that it is not agreeable that the building has yet implemented the solar energy system. Next, Figure 3 shows the Indoor Environmental Quality element. Based on the results, it shows that all of the elements have achieved more than 3.5 mean index, which could be concluded that the element of indoor environmental quality is fulfilled. The mean index for the Sustainable Site Planning and Management is shown in Figure 4 and it shows that most of the subelements scored higher than 3.5 which means it is acceptable with the highest score of 4.0 for the number of parking provided is sufficient. However, one of the sub-elements, the statement roof material used is suitable so the solar heat is not greatly transferred into the building scored 3.35 which means it is not yet fully fulfilled the element criteria since the building is currently using the conventional concrete roof tiles. Next, Figure 5 shows Materials and Resources element. The figure shows that all of the sub-elements have mean index lower than 3.5, which mean all of the sub-elements have not yet meet the requirements for this element. Figure 6 next shows the Water Efficiency element and it also shows that this element has not yet fulfilled since all of the sub-elements scored less than the 3.5 mean index. The last element which is the Innovation can be seen in the Figure 7 also shows that all the sub-elements score less than 3.5. Therefore, in this case the data could show that the only element that the Sultan Ismail Parliament building has fully achieved is the Indoor Environmental Quality. The element of Energy Efficiency and Sustainable Site Planning and Management are partially fulfilled. While the Materials and Resources, Water Efficiency and Innovation have not yet fulfill the green building strategy. Thus, all of the sub-elements which scored less than 3.5 mean index should be taken into consideration for the use of retrofitting in the future.

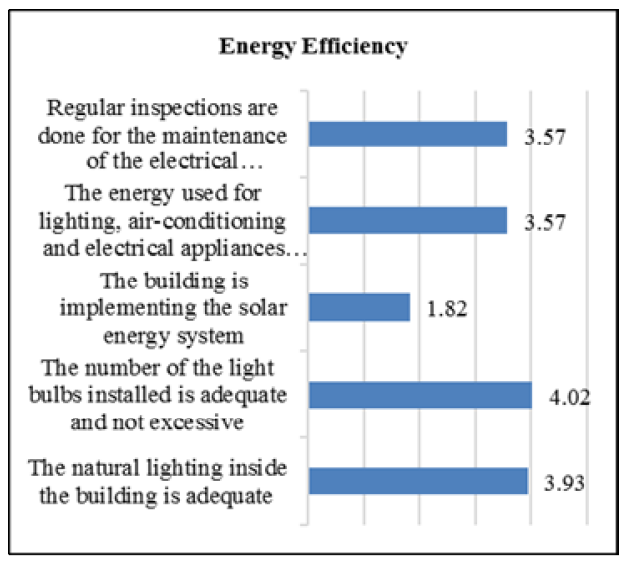

Fig.2. Energy Efficiency.

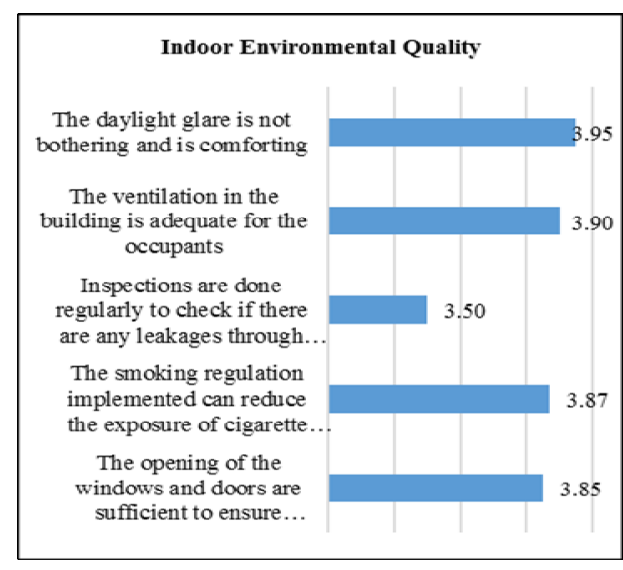

Fig.3. Indoor Environmental Quality. 


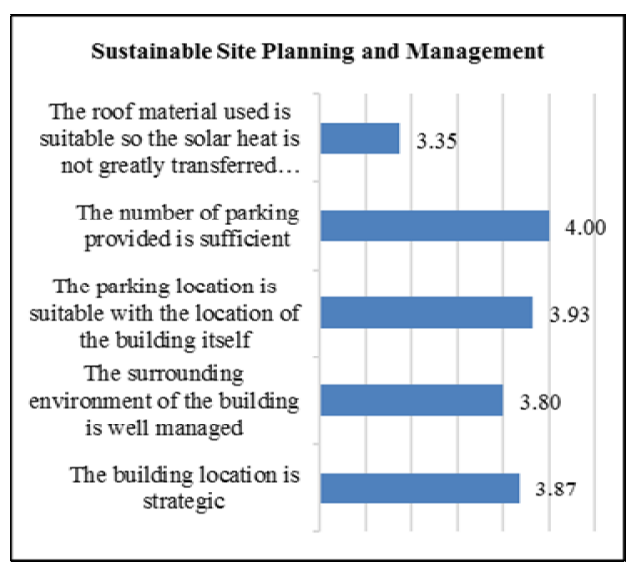

Fig.4. Sustainable Site Planning and Management.

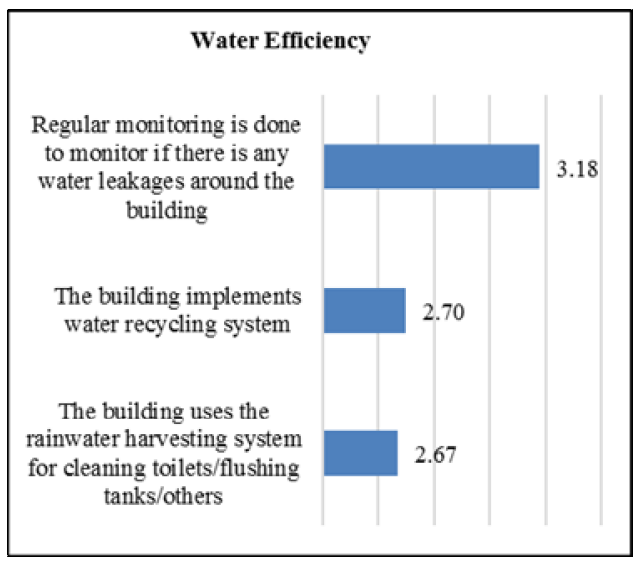

Fig.6. Water Efficiency.

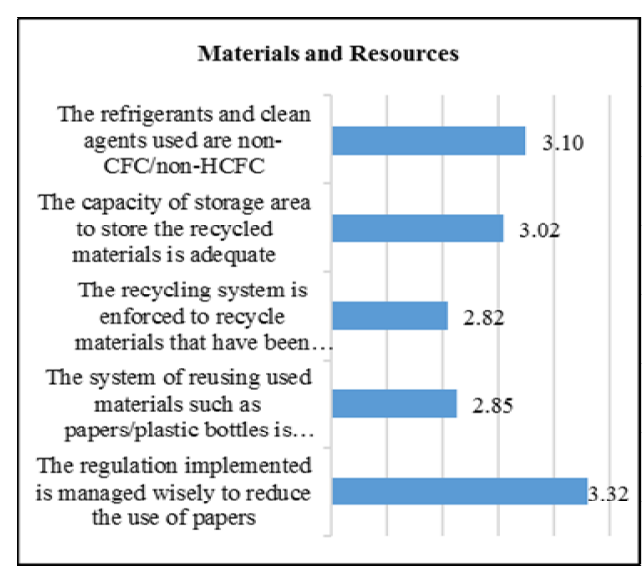

Fig.5. Materials and Resources.

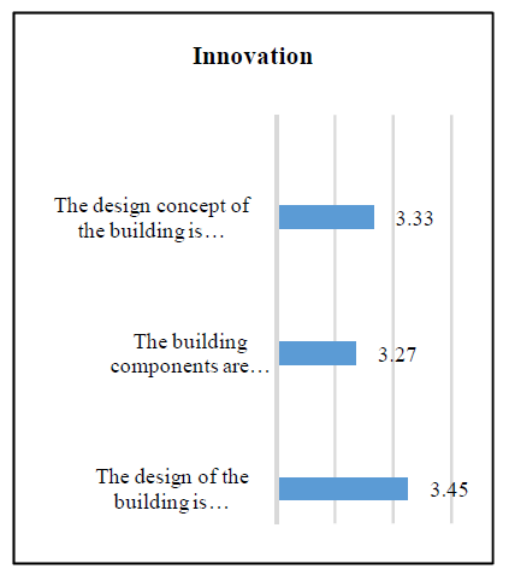

Fig.7. Innovation.

\subsection{To propose retrofit for existing Sultan Ismail Parliament Building to green building}

Based on Figure 8, all the items that have been listed to be proposed were scored above 3.5 mean index which shows that all the items are acceptable to be used later. The highest ranked item is to encourage the recycling and other waste management practices with mean 4.23. In workplaces such as the offices are encouraged to practice recycling and also the combination of recycling and waste prevention programs. It promotes not only recycling but also to reduce paper consumption and to reuse office supplies. The second item is to encourage the use of renewable energy technologies with mean index of 4.13. It shows that the respondents are agreeing that renewable energy could be implemented in the building. Renewable energy is essentially harnessing the power of the sun and wind. For example, the initiative that could be taken is by replacing a part of the conventional roof tiles to Photovoltaic (PV) or solar cells where the PV modules could convert sunlight into direct current. The third item is to install motion sensor for lighting system with a mean index of 
4.12. A motion sensor can either replace conventional lighting switches or to be placed on an existing lighting fixture. The motion sensing lighting system is ideal for lighting areas that only being used briefly or as long as someone is there. The light will automatically switched off after a few minutes after there are no motion detected. Thus, electricity wastage can be prevented. While the lowest ranked is to install shading to reduce sunlight glare with a mean index of 3.53 .

\section{Potential Retrofit of Existing S ultan Ismail Parliament Building}

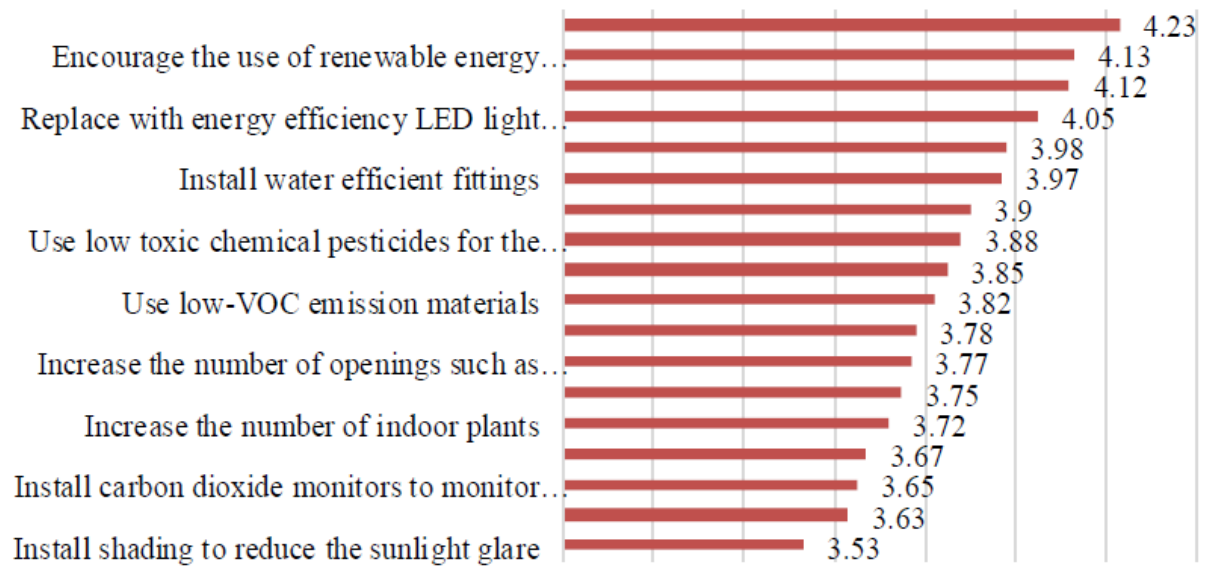

Fig.8. Potential Retrofit of Existing Building to Green Building.

\subsection{Correlation Analysis}

Spearman's Correlation Coefficient analysis was done to test the strength of the associations between two variables.

Table 1. Correlation of Two Variables (Dependent Variable: Energy Efficiency)

\begin{tabular}{|l|c|c|}
\hline \multicolumn{1}{|c|}{ Independent Variable } & $\begin{array}{c}\text { (Spearman Correlation - } r_{\mathrm{s}} \text { ) } \\
\text { Energy Efficiency }\end{array}$ & $\mathrm{P}$ (Significant Level) \\
\hline Indoor environmental quality & 0.572 & 0.0001 \\
\hline $\begin{array}{l}\text { Sustainable site planning and } \\
\text { management }\end{array}$ & 0.406 & 0.0010 \\
\hline Materials and resources & 0.301 & 0.0200 \\
\hline Water efficiency & 0.461 & 0.0001 \\
\hline Innovation & 0.493 & 0.0001 \\
\hline
\end{tabular}

Table 1 shows the strength of the associations for Energy Efficiency with other elements could be considered as associated. Based on the table above, the strongest correlation is between Energy Efficiency and Indoor Environmental Quality with rs value of 0.572 which means that Energy Efficiency is moderately dependent to the Indoor Environmental Quality element. While the association between Energy Efficiency and other elements are weak and moderate. The significant level for all the elements is less than 0.05 , which means the values are acceptable. Hence, it shows that there is a relevant correlation between Energy Efficiency with all other elements in the green building concept. 


\section{Conclusion}

The study shows that the importance of retrofitting. This includes the reduction of energy consumption, reduction of greenhouse gas emission, improves working environment, increases the usage of renewable energy and reduce cost of water used. The study also shows the potential retrofit that could be applied to the Sultan Ismail Parliament building has been identified. The result shows that the building has only fully fulfilled one of the green building elements which is the 'Indoor Environmental Quality'. While, other elements should be considered for later use of retrofitting. Among the unfulfilled elements, it shows that waste management should be taken into account to improve the building materials and resources management. This study also identified that the most relevant steps that could be proposed for retrofit are to encourage the recycling and other waste management practices, to encourage the use of renewable energy technologies and to install motion sensor or auto sensor for lighting system.

\section{References}

[1] R. Zakaria, K. S. Foo, R. Mohammad Zin and S. Zolfagharian, Potential Retrofitting of Existing Campus Buildings to Green Buildings. J. of Applied Mechanics and Materials, 178-181, 42- 45, (2012)

[2] M.C. Lee K. M, Building and Environment, 238- 244, (2012)

[3] M. N. Yasin, A. H. Abdullah, R. Yunus, H. Abdul Khalid, and N. S. N. Wahab, Potential Retrofit of Universiti Tun Hussein Onn Malaysia Existing Building towards Green Building, ICTMBE Conference, (2015)

[4] Malaysia Green Building (GBI) Index, (2015), Retrieved on June 3, 2016 from $\mathrm{http} /$ www.greenbuildingindex.org,

[5] Ministry of Energy, Water and Green Technology Malaysia, (2014), Retrieved on June 3, 2016 from http://www.kettha.gov.my

[6] Garnaut, R, The Garnaut Climate Change Review. Final Report. Cambridge University Press, Melbourne, Australia. ISBN: 9780521744447, (2007)

[7] L. Tobias and G. Vavaroustos, Retrofitting office buildings to be green and energyefficient, Urban Land Institute, (2009)

[8] Kota Iskandar Website, (2016), Retrieved on September 3, 2016 from http//www.kotaiskandar.com,

[9] Cahaya Jauhar, (2015), Retrieved on September 3, 2016 from http://cahayajauhar.com, 